\title{
Erratum zu: NGOs als besondere Akteure der Interessenvermittlung
}

\section{Erratum zu:}

M. Schiffers, NGOs als besondere Akteure der Interessenvermittlung, Studien der NRW School of Governance, https://doi.org/10.1007/978-3-658-34851-9

Die EPUB- und HTML-Versionen des Buches wurden mit einem unvollständigen Untertitel veröffentlicht, dies wurde nun korrigiert. 